\title{
Pituitary adenylate cyclase activating polypeptide concentrations in the sheep mammary gland, milk, and in the lamb blood plasma after suckling
}

\author{
K. POHÓCZKY ${ }^{1,2,3}$, A. TAMÁS ${ }^{4}$, D. REGLŐDI ${ }^{4}$, Á. KEMÉNY ${ }^{1,5}$, \\ ZS. HELYES ${ }^{1,2 *}$ (D) and L. CZEGLÉDI ${ }^{6 \dagger}$
}

\footnotetext{
${ }^{1}$ Department of Pharmacology and Pharmacotherapy, University of Pécs Medical School, Pécs, Hungary

2 János Szentágothai Research Centre, Centre for Neuroscience, University of Pécs, Pécs, Hungary

${ }^{3}$ Department of Pharmacology, University of Pécs Faculty of Pharmacy, Pécs, Hungary

${ }^{4}$ Department of Anatomy, MTA-PTE PACAP Research Team, Centre for Neuroscience, University of Pécs Medical School, Pécs, Hungary

${ }^{5}$ Department of Medical Biology, University of Pécs Medical School, Pécs, Hungary

${ }^{6}$ Institute of Animal Science, Faculty of the Agricultural and Food Sciences and Environmental

Management, University of Debrecen, Debrecen, Hungary
}

Received: June 22, $2019 \bullet$ Accepted: January 07, 2020

Published online: April 14, 2020

(c) 2020 The Author(s)

\begin{abstract}
Pituitary adenylate cyclase activating polypeptide (PACAP) is involved in development and reproduction. We previously described elevated PACAP levels in the milk compared to the plasma, and the presence of its specific PAC1 receptor in the mammary gland. This study aimed to determine PACAP and vasoactive intestinal peptide (VIP) levels in female suckling lambs compared to ewe plasma and mammary gland, as well as their age-dependent alterations. mRNA expressions of PACAP, VIP, PAC1 receptor and brain-derived neurotrophic factor (BDNF) were quantified in the milk whey and mammary gland. PACAP38-like immunoreactivity (PACAP38-LI) was measured in plasma, milk whey and mammary gland by radioimmunoassay, VIP-LI by enzyme-linked immunoassay. PACAP38-LI was 5, 6
\end{abstract}

\footnotetext{
* Corresponding author. Department of Pharmacology and Pharmacotherapy, University of Pécs Medical School, H-7624, Szigeti street 12, Pécs, Hungary. Phone: +36 72536 001, E-mail: zsuzsanna.helyes@aok.pte.hu

${ }^{\dagger}$ The two authors contributed equally to this work.
} 
times higher in the milk compared to the plasma of lactating sheep. It significantly increased in the lamb plasma $1 \mathrm{~h}$, but returned to basal level $2 \mathrm{~h}$ after suckling. However, VIP mRNA was not present in the mammary gland, we detected the VIP protein in the milk whey. BDNF mRNA significantly decreased with age to approximately $60 \%$ and $25 \%$ in the 3-and 10-year-old sheep respectively, compared to the 3month-old lambs. No differences were found between mammary and jugular vein plasma PACAP and VIP concentrations, or during the daily cycle. We propose a rapid absorption of PACAP38 from the milk and/or its release in suckling lambs. PACAP accumulated in the milk might be synthesized in the mammary gland or secreted from the plasma of the mothers. PACAP is suggested to have differentiation/ proliferation promoting and immunomodulatory effects in the newborns and/or a local function in the mammary gland.

\section{KEYWORDS}

PACAP, VIP, PAC1 receptor, BDNF, sheep, mammary gland, gene expression, development

\section{INTRODUCTION}

Pituitary adenylate cyclase activating polypeptide (PACAP) was first isolated from ovine hypothalamic extracts. Based on the structural homology (68\%) of its N-terminal amino acid sequence with the vasoactive intestinal peptide (VIP) it is considered to belong to the VIP/ glucagon/secretin family [1]. PACAP exists in two biologically active forms, PACAP27 and PACAP38, alternatively processed from the same precursor, with PACAP38 being the dominant form in mammals [2]. Although PACAP has poor metabolic stability and short plasma elimination half-life, it exerts important biological activities [3,4]. Since its discovery, PACAP has been described in peripheral organs throughout the body and its effects are mediated by specific receptors on the target cells: the PACAP-preferring PAC1 receptor and two VIP-shared VPAC1 and VPAC2 receptors [5].

Several factors influence milk composition, such as animal species, breed, feeding and environment. It contains - among others - high levels of various proteins, vitamins, hormones and growth factors, antimicrobial substances and immunoglobulins, which play important roles in neonatal development and lactation [6]. Some growth factors are transferred from plasma without any modification regarding activity and structure. Others are synthesized in the mammary gland, such as epidermal growth factor, insulin-like growth factor, prolactin and gonadotropin-releasing hormone [7]. Sheep and goat milk contain particularly high-quality proteins and bioactive compounds, such as cytokines, growth factors, peptides and hormones [6], nucleotides and ribonucleosides [8]. We have previously described the presence of PACAP38 in the milk of various domestic animals (sheep, goat and cow) and humans, where we found significantly elevated PACAP concentrations in the colostrum samples compared to transitional and mature milk [9-11]. PACAP is present in the milk whey of small ruminants at concentrations 5-20 times higher than in the plasma, and does not change during the first 3 months of lactation [11]. It is proposed that PACAP acts on the infant intestinal tract directly and after being transferred to the circulation, it might influences organ development. Moreover, 
PACAP can also affect development, growth and hormonal activity of the mammary gland itself and it might have a protective action on aging-related processes $[9,11,12]$.

Brain-derived neurotrophic factor (BDNF) is a member of the neurotrophin family described in the development and survival of neuronal cells. A link between PACAP and BDNF has been described in the central nervous system (CNS, [13]). A recent article reports the presence and lactation-dependent alterations of BDNF in the sheep mammary gland [14]. The author suggests that the presence of BDNF acts as a paracrine/autocrine signal responsible for crosstalk between hormonal stimulation and the local micro environment. Since the observed correlation between BDNF and lactation appeared to be interesting, we investigated how BDNF expression in the sheep mammary gland changes with aging in parallel with PACAP levels.

In the present study our aims were to determine the alterations of PACAP in comparison with the related peptide VIP 1) in the plasma of lambs in a time-dependent manner after suckling; 2 ) in the plasma related to age; 3 ) in the milk in comparison with the respective plasma value and during the daily cycle. Furthermore, we also examined the expression of PACAP, VIP, their receptors and BDNF by studying their mRNAs in the mammary gland.

\section{MATERIALS AND METHODS}

\section{Animals and sample collection}

Samples were collected from Hungarian Tsigai sheep according to a protocol approved by the Institutional Ethic Committee (license number: 28/2012 DE MAB). Animals were kept in a stable during winter and were grazing from April. Plasma and milk samples of ewes and lambs were collected from sheep kept at an experimental farm of the University of Debrecen. The slaughtered animals were kept at a private sheep farm, "Balmazujvaros, Hungary". Samples were collected under calm circumstances in a standardized manner, causing minimal distress for the animals.

\section{Plasma samples}

After local disinfection of the skin surface, plasma samples were collected into ice-cold evacuated plastic plasma collection tubes (Vacutainer ${ }^{\circledR}$, BD Life Sciences, Franklin Lakes NJ USA) containing the anticoagulant ethylenediaminetetraacetic acid (EDTA, $18 \mathrm{mg}$, Sigma Aldrich, St Louis MO USA) and the peptidase inhibitor aprotinin $1.4 \mathrm{mg}$ aprotinin/1 mL distilled water; $20 \mu \mathrm{L}$ solution/1 mL plasma sample (Sigma-Aldrich, St Louis MO USA). After centrifugation $\left(600 \times g\right.$ for $10 \mathrm{~min}$ and $950 \mathrm{~g}$ for $10 \mathrm{~min}$ at $4{ }^{\circ} \mathrm{C}$ ) plasma was removed and stored at $-80^{\circ} \mathrm{C}$ for further investigations. For the suckling-related measurements, $10 \mathrm{~mL}$ plasma samples were taken from the jugular vein by the same method from 3-month-old female suckling lambs $(n=9)$ before $(0 \mathrm{~h})$ and 1 and $2 \mathrm{~h}$ after suckling $(1 \mathrm{~h}, 2 \mathrm{~h})$. In addition, samples were also taken from the jugular and mammary veins of their 3-year-old mothers $(n=8)$, representing systemic venous plasma and that directly from the mammary gland vein, respectively.

\section{Milk samples}

In general, milk samples ( $5 \mathrm{~mL} / \mathrm{animal})$ of lactating ewes were harvested in the morning into icecold centrifuge tubes. To evaluate daily changes of PACAP38-like immunoreactivity 
(PACAP38-LI) in milk whey, we collected milk samples from 4 lactating ewes ( $5 \mathrm{~mL} / \mathrm{animal})$, at 6 different time points (0:00,04:00, 08:00, 12:00, 16:00 and 20:00).

\section{Slaughtering}

Animals were slaughtered following a conventional procedure according to EU regulations (Council Regulation (EC) No 1099/2009 of 24 September 2009) on the protection of animals at the time of slaughter. Briefly, sheep providing tissue samples were stunned on the forehead with a captive bolt pistol followed by incision of blood vessels immediately. Prior to stunning a sheep, the other animals involved in the experiment were separated to exclude the possibility of viewing the slaughter procedure. Ten milliliters blood, $1 \mathrm{~cm}^{3}$ mammary gland (from the glandular component of the mammary gland) and uterus samples (as positive controls for VIP mRNA expression) were harvested from 3-month-old ( \pm 2 weeks), 3-year-old ( \pm 4 months) and 10-yearold ( \pm 1 year) animals $(n=4$ /group) immediately after slaughtering. One part of each mammary gland and uterus sample was placed into RNA-later (Sigma-Aldrich, St Louis MO USA) for qPCR analysis. The other parts of these samples were immediately deep frozen at $-80{ }^{\circ} \mathrm{C}$ for radioimmunoassay (RIA) and enzyme-linked immunoassay (ELISA) measurements of the peptides.

\section{RIA measurements}

PACAP38-LI in the plasma, milk and mammary gland was determined with a sensitive PACAP38-specific RIA technique developed in our laboratory and concentrations of the peptide were calculated with the help of a calibration curve $[15,16]$. The "ab35342" (Abcam, Cambridge, UK) PACAP38 antiserum was raised in sheep against the synthetic peptide (human) conjugated to keyhole limpet hemocyanin. The antiserum used in the RIA is C-terminal specific, without affinity for other members of the VIP/secretin/glucagon peptide family. The average $\mathrm{ID}_{50}$ value was $48.6 \pm 3.4 \mathrm{fmol} / \mathrm{mL}$ determined in 10 consecutive assays. Synthetic peptides were used as RIA standard ranging from 8 to $2,000 \mathrm{fmol} / \mathrm{mL}$. Intra-assay and inter-assay coefficients of variation were $8.2 \%$ and $12.3 \%$, respectively.

Protein content of a $2 \mathrm{~mL}$ plasma sample was extracted with the mixture of $3 \mathrm{~mL}$ absolute ethanol and $10 \mu \mathrm{L} \mathrm{96 \%} \mathrm{acetic} \mathrm{acid.} \mathrm{Tubes} \mathrm{were} \mathrm{incubated} \mathrm{at} \mathrm{room} \mathrm{temperature} \mathrm{(RT)} \mathrm{for} 20 \mathrm{~min}$, followed by centrifugation at $950 \times g$ at $4{ }^{\circ} \mathrm{C}$ for $20 \mathrm{~min}$. The supernatant was collected into a reaction tube and dried under nitrogen-flow at room temperature for $6 \mathrm{~h}$. The dried supernatant was suspended in $300 \mu \mathrm{L}$ RIA buffer (previously described in detail: 16), and then centrifuged at $10,000 \times g$ for $15 \mathrm{~min}$. One reaction tube contained $450 \mu \mathrm{L}$ suspended dry plasma sample or $100 \mu \mathrm{L}$ mono- ${ }^{125}$ I-labeled PACAP24-38 C-terminal fragment as tracer (3,000 cpm/tube), $100 \mu \mathrm{L}$ antiserum (working dilution of 1:10,000), and $350 \mu \mathrm{L}$ RIA assay buffer. After $48 \mathrm{~h}$ incubation at $4{ }^{\circ} \mathrm{C}$, the antibody-bound peptide was separated from the free one by the addition of $100 \mu \mathrm{L}$ separating solution (content described previously in: 15). Samples were centrifuged at $950 \times g$ for $20 \mathrm{~min}$ at $4{ }^{\circ} \mathrm{C}$, tubes were gently decanted and the radioactivity was measured by a gamma counter (Gamma, type: NZ310). The detection range of PACAP38-LI for the plasma samples was between 16 and $1000 \mathrm{fmol} / \mathrm{mL}$. The RIA procedures were the same in the case of the milk whey and mammary gland homogenates, only sample preparation steps were different as described below. 
Ten milliliters $98 \%$ acetic acid was added to $1 \mathrm{~mL}$ milk sample and incubated in a $40{ }^{\circ} \mathrm{C}$ water bath for $5 \mathrm{~min}$ to precipitate the protein content. Samples were then centrifuged at 10 ${ }^{\circ} \mathrm{C}, 950 \times g$ for $10 \mathrm{~min}$ at $4{ }^{\circ} \mathrm{C}$ to obtain a solid fat component from the top of the samples. The whey localized between fat and the precipitated protein fraction was removed for RIA analysis. The detectable amount of PACAP in milk whey ranged from 125 to $2000 \mathrm{fmol} / \mathrm{mL}$. Mammary gland tissue samples $(280 \mathrm{mg}$ ) were homogenized in $2 \mathrm{~mL}$ distilled water containing a protease inhibitor cocktail (Sigma-Aldrich, St. Louis, MO, USA) using a tissue homogenizer (MICCRA D-15), then samples were centrifuged at $600 \times g$ at $4{ }^{\circ} \mathrm{C}$ for $15 \mathrm{~min}$. The supernatant was harvested into ice-cold tubes and centrifuged at $10,000 \times g$ at $4{ }^{\circ} \mathrm{C}$ for 15 min. The detection range of PACAP38-LI for the tissue homogenates was between 16 and $1000 \mathrm{fmol} / \mathrm{mL}$.

\section{Enzyme-linked immunoassay (ELISA)}

We measured VIP-LI in the same plasma and milk samples as described for PACAP38-LI, using a specific ELISA Kit (Sincere ${ }^{\mathrm{TM}}$, Sincere Biotech Co., Ltd, Beijing, China) according to the manufacturer's protocol that is proven to be specific for ovine VIP. The reaction was evaluated at an absorbance of $450 \mathrm{~nm}$ using a Multiskan RC microplate reader (Labsystems, Thermo Scientific, Waltham, MA, USA). The optical density (OD) of the control wells was subtracted from that of each sample and standard. The VIP concentration of the samples was calculated using the standard curve. The detection range of the measurement was $7.8-500 \mathrm{pg} /$ $\mathrm{mL}$, the sensitivity of the assay $<2.0 \mathrm{pg} / \mathrm{mL}$. The intra-assay and inter-assay precision of the analysis were 8 and $12 \%$, respectively.

\section{RNA extraction and primer design}

Mammary gland samples stored in RNA Later (Sigma-Aldrich, St. Louis, MO, USA) were homogenized in $1 \mathrm{~mL}$ of TRI Reagent (Molecular Research Centre Inc., Cincinnati, OH, USA) and total RNA was isolated using the Direct-Zol ${ }^{\mathrm{TM}}$ RNA isolation kit (Zymo Research, Irvine, CA, USA) according to the manufacturer's instructions. The RNA samples were then treated with $1 \mathrm{U}$ DNase I (Zymo Research, Irvine, CA, USA) at $37{ }^{\circ} \mathrm{C}$ for $1 \mathrm{~h}$, then quantified using a NanoDrop1000 Spectrophotometer (Thermo Scientific, Bonn, Germany). One microgram RNA (diluted in $10 \mu \mathrm{L}$ nuclease-free water) was reverse transcribed into complementary DNA (cDNA) using oligod $(\mathrm{T})_{18}$ primers and the Maxima ${ }^{\mathrm{TM}}$ First Strand cDNA Synthesis Kit for RTqPCR (Thermo Scientific, Waltham, MA, USA) in $20 \mu \mathrm{L}$ final volume, using an Eppendorf Mastercycler DNA Engine Thermal Cycler PCR (Eppendorf Austria GmbH, Wien, Austria). Primer pairs were designed with the primer design software of the National Center for Biotechnology Information (www.ncbi.nlm.nih.gov/tools/primer-blast/). RT-qPCR primers and product lengths for each gene are listed in Table 1 according to the revised COGNOSAC guideline for the gene nomenclature in ruminants [17]. The specificities and amplification efficiencies of the primers were calculated using BLAST and the Stratagene Mx3000P QPCR System (Agilent Technologies, Santa Clara, CA, USA). The efficiency values of the primers were found to be as follows: $\beta$-actin: $102.4 \%$ (reference gene), PACAP: $92.6 \%$, PAC1: $92.2 \%$, BDNF: $80.8 \%$, VIP primer number: $1: 89.6 \%$, VIP primer number: $2: 80.3 \%$. Primer efficiencies were taken into account when calculating gene expression ratios [18]. 
Table 1. Details of oligonucleotide primer sequences used in qPCR measurements

\begin{tabular}{|c|c|c|c|c|c|}
\hline $\begin{array}{l}\text { Gene } \\
\text { amplified }\end{array}$ & Nucleotide sequence of primer & $\begin{array}{l}\text { Primer } \\
\text { type }\end{array}$ & $\begin{array}{l}\text { Number of base pairs } \\
\text { in DNA fragment } \\
\text { amplified (bp) }\end{array}$ & $\begin{array}{l}\text { Nucleotide } \\
\text { range of primer } \\
\text { sequence }\end{array}$ & $\begin{array}{l}\text { NCBI } \\
\text { reference } \\
\text { sequence }\end{array}$ \\
\hline Beta-actin & $\begin{array}{l}\text { GCT GTG CTG TCC CTG TAC GC } \\
\text { GCG GAT GTC GAC GTC ACA C }\end{array}$ & $\begin{array}{l}\text { sense } \\
\text { antisense }\end{array}$ & 459 & $498-956$ & NM_001009784.1 \\
\hline PACAP & $\begin{array}{l}\text { AAATACTTGGCGGCTGTCCT } \\
\text { GTACGGTATTCGCCGTCCTT }\end{array}$ & $\begin{array}{l}\text { sense } \\
\text { antisense }\end{array}$ & 72 & $1030-1101$ & NM_001009776.1 \\
\hline PAC1 & $\begin{array}{l}\text { ACA GGC TGC TGG GAT ATG AAT G } \\
\text { AGA GTA ATG GTG GAC AGT TCT G }\end{array}$ & $\begin{array}{l}\text { sense } \\
\text { antisense }\end{array}$ & 251 & $1037-1287$ & XM_015095317.1 \\
\hline BDNF & $\begin{array}{l}\text { ACG AGA CCA AGT GCA ATC CC } \\
\text { GCA CGT ACG ACT GGG TAG TT }\end{array}$ & $\begin{array}{l}\text { sense } \\
\text { antisense }\end{array}$ & 102 & 915-1016 & XM_004016359.2 \\
\hline VIP (1) & $\begin{array}{l}\text { AGG GAC CAA TCA AAC GCC AC } \\
\text { GAC TCT CCT TCG CTG CTT CTC }\end{array}$ & $\begin{array}{l}\text { sense } \\
\text { antisense }\end{array}$ & 127 & $356-482$ & NM_001126368.1 \\
\hline VIP (2) & $\begin{array}{l}\text { GCGTACTCTTCTCCCAGACC } \\
\text { ATTCTGTCCCCCATCCTCAGA }\end{array}$ & $\begin{array}{l}\text { sense } \\
\text { antisense }\end{array}$ & 73 & $50-122$ & NM_001126368.1 \\
\hline VPAC1 & $\begin{array}{l}\text { TCT TCT CCC CCA TTC AAG GC } \\
\text { AAC ACT GTC TGC TGC TGC T }\end{array}$ & $\begin{array}{l}\text { sense } \\
\text { antisense }\end{array}$ & 145 & $384-528$ & XM_004018593.3 \\
\hline VPAC2 & $\begin{array}{l}\text { TGT TCA GAC ATG AGA GTG GGT } \\
\text { CTG AAT GCC GCT TGA GTC TT }\end{array}$ & $\begin{array}{l}\text { sense } \\
\text { antisense }\end{array}$ & 150 & $2023-2152$ & XM_015095467.1 \\
\hline
\end{tabular}

Abbreviations: PACAP = pituitary adenylate cyclase activating polypeptide; PAC1 = pituitary adenylate cyclase activating polypeptide receptor 1 ; $\mathrm{BDNF}=$ brain-derived neurotrophic factor; VIP $=$ vasoactive intestinal peptide, VPAC1 $=$ vasoactive intestinal peptide receptor 1,

VPAC2 = vasoactive intestinal peptide receptor 2. 


\section{Quantitative real-time polymerase chain reaction (qPCR) and data analysis}

The reaction was set up in three technical replicates in a volume of $20 \mu \mathrm{L}$ containing $20 \mathrm{ng}$ cDNA, $1 \times$ Luminaris Color HiGreen Low ROX qPCR Master Mix (ready-to use master mix contains hot start Taq DNA polymerase in combination with an optimized buffer, Thermo Scientific, Waltham, MA, USA), and $0.3 \mu \mathrm{M}$ of each primer. Cycling conditions for amplification were as follows: $95{ }^{\circ} \mathrm{C}$ for $10 \mathrm{~min}$, followed by 40 cycles of $95^{\circ} \mathrm{C}$ for $15 \mathrm{sec}, 60{ }^{\circ} \mathrm{C}$ for 45 sec and $72{ }^{\circ} \mathrm{C}$ for $45 \mathrm{sec}$. The analysis was conducted using the Stratagene Mx3000P QPCR System (Agilent Technologies, Santa Clara, CA, USA), equipped with a 96-well optical reaction plate. The relative expression ratios were calculated using MxPro QPCR Software (Agilent Technologies, Santa Clara, CA, USA) with $\Delta \Delta$ Ct method, and normalized to $\beta$-actin as a reference gene, showing stable expression in the mammary gland samples independently of age. The samples of 3-month-old animals served as the control group. Product size was routinely controlled by agarose gel electrophoresis. RNA samples without reverse transcription did not give any amplification products with the primers used, indicating that genomic DNA contamination was not present. PCR set-up of the VIP-specific semi-quantitative PCR

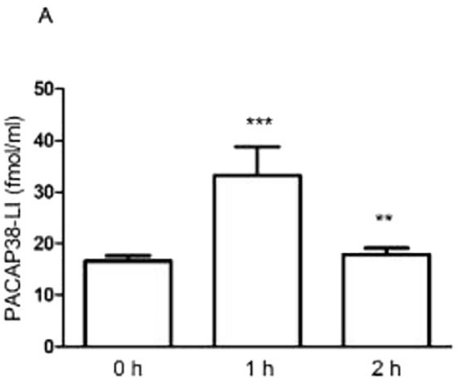

C

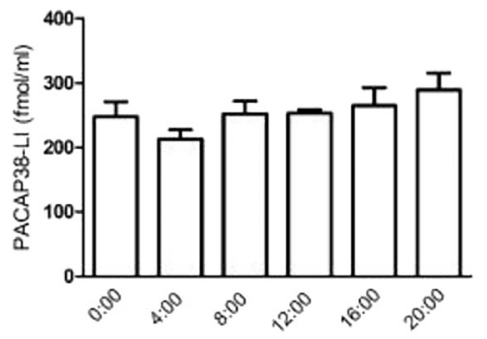

B

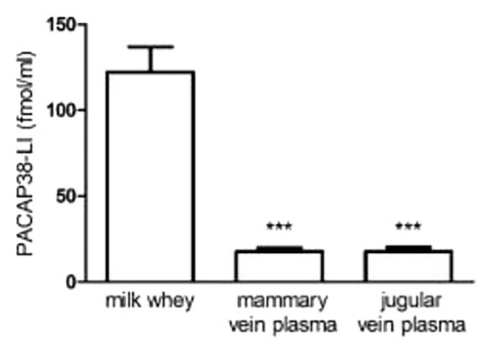

D

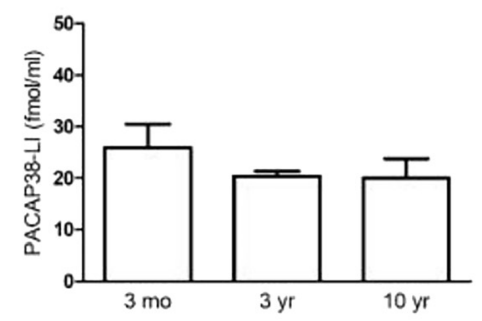

Fig. 1. PACAP38-like immunoreactivity (PACAP38-LI) determined by RIA (A) in the lamb plasma before, as well as 1 and $2 \mathrm{~h}$ after suckling ( $n=9$ /group). PACAP38-LI in the mammary and jugular vein plasma in comparison with milk whey of (B) 3-year-old mother ewes ( $n=8$ /group), (C) daily changes of PACAP38$\mathrm{LI}$ in the milk of lactating ewes $(n=4$ /group) and (D) plasma PACAP38-LI in the jugular vein of the 3 age groups ( $n=4$ /group). Statistical analysis: one-way ANOVA, Bonferroni's post test. Results are shown as means $\pm \mathrm{SEM}, * * P<0.005,{ }^{* * *} P<0.0001$. Abbreviations: mo: month, yr: years 
measurement was conducted as described above. The PCR products were electrophoresed on a 2.5\% agarose gel containing 0.01\% GelRed (Biotium, Harward CA, USA) at $70 \mathrm{~V}$ for $40 \mathrm{~min}$, and visualized by Safe View (Cleaver Scientific Ltd, Warwickshire, UK) transilluminator (Supplementary Fig. 1). The image acquisition was performed using the Vilber-Lourmat Bio-Profil (version 97) gel documentation system with Bio-Capt Software (version 12.6).

\section{Statistical analysis}

All calculations were made by a licensed copy of GraphPad Prism 6.0. software (http://www. graphpad.com/scientific-software/prism/, GraphPad Software Inc, La Jolla, CA). Data are expressed as mean \pm SEM. The normal distribution of data was tested using the KolmogorovSmirnov test. In order to determine the statistical significance between 3 or more columns analyzed altogether, one-way ANOVA followed by the Bonferroni's post-test was used in all cases. The Pearson rank correlation coefficient was used to compute the correlation between PACAP, PAC1 receptor and BDNF mRNA expression in the mammary gland. In all cases, $P<$ 0.05 was considered statistically significant.

\section{RESULTS AND DISCUSSION}

\section{Concentrations of PACAP38-LI in the plasma and milk of sheep}

PACAP38-LI was approximately $20 \mathrm{fmol} / \mathrm{mL}$ in the plasma of lambs before suckling, which showed an almost 2 -fold increase $(P<0.001) 1 \mathrm{~h}$ later and returned to basal value $2 \mathrm{~h}$ after suckling (Fig. 1A). There was no significant difference between PACAP38 levels obtained from the jugular and mammary vein plasma samples (Fig. 1B). PACAP38 concentration in the milk whey of ewes was about 10 times higher as compared to the plasma samples taken from the jugular and mammary veins $(P<0.0001)$, but we did not detect changes in PACAP excretion in milk during the daily cycle (Fig. 1C). Plasma PACAP38-LI concentrations were similar in the three age groups (Fig. 1D).

\section{Expression of PACAP mRNA and alteration of peptide levels in the mammary gland}

The relative gene expression of PACAP was similar in all the three age groups (Fig. 2A). PACAP38-LI showed an apparent trend to increase in the 3-year-old ewes (lambs vs. 3-year-old group, $P=0.075$ ) and in the 10 -year-old group (lambs vs. 10 -year-old ewes, $P=0.196$ ), but showed individual differences (Fig. 2B). In comparison, the PACAP-related peptide, VIP was not expressed in the mammary gland of any age group, as shown by the lack of the presence of its mRNA measured by semi-quantitative PCR (Supplementary Fig. 2, lower panel). The validity of our method was confirmed by the detection of VIP transcripts with both sets of primers in all age groups in the sheep uterus, as a positive control (Supplementary Fig. 2 upper panel).

\section{Age-related PAC1 receptor and BDNF mRNA expressions and alterations in the mammary gland}

The expression of PAC1 receptor mRNA followed a gradually increasing tendency without any significant differences between the lambs, 3-year-old and 10-year-old sheep (Fig. 3A). BDNF 


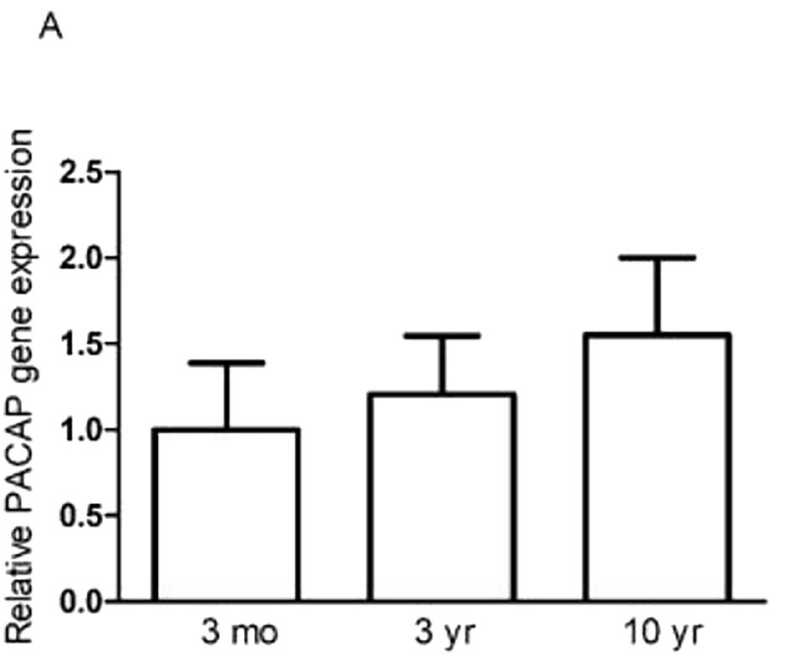

B

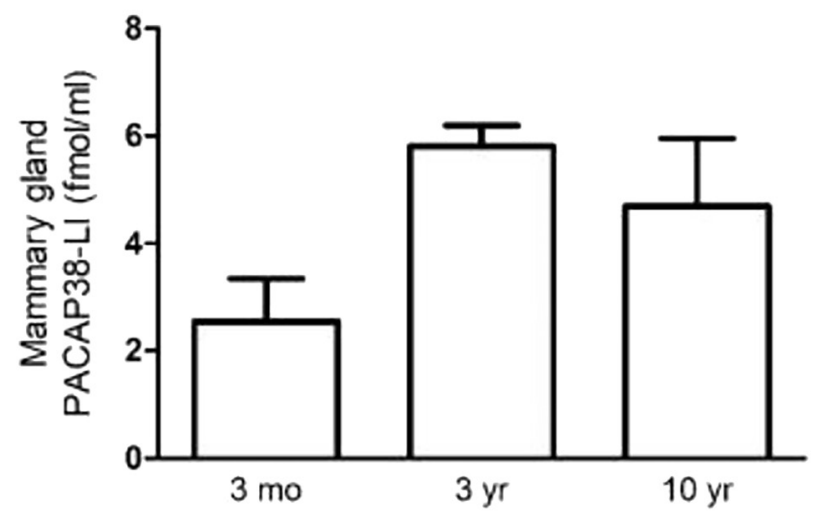

Fig. 2. Relative gene expression ratio of (A) PACAP and (B) PACAP38-LI of 3-month- (mo), 3-year- (3 yr) and 10-year-old $(10 \mathrm{yr})$ sheep mammary gland samples $(n=4$ /group). Statistical analysis: one-way ANOVA, Bonferroni's post test. Results are shown as means \pm SEM.

decreased with age: the mRNA levels were strongly down-regulated by $30 \%(P<0.0001)$ and $60 \%(P<0.0001)$ in 3 - and 10-year-old sheep, respectively, as compared to lambs (Fig. 3B). However, no correlation was found between BDNF and PACAP or PAC1 gene expression ratios in any age group (data not shown, Pearson rank correlation coefficient). VPAC1/VPAC2 mRNA could not be detected either in the udder or in the uterus tissues using the primers exclusively available for sheep shown in Table 1. 
A

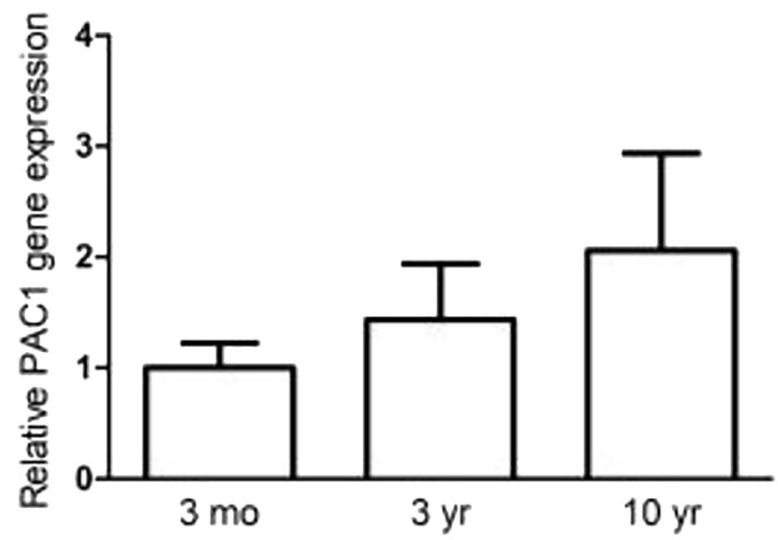

B

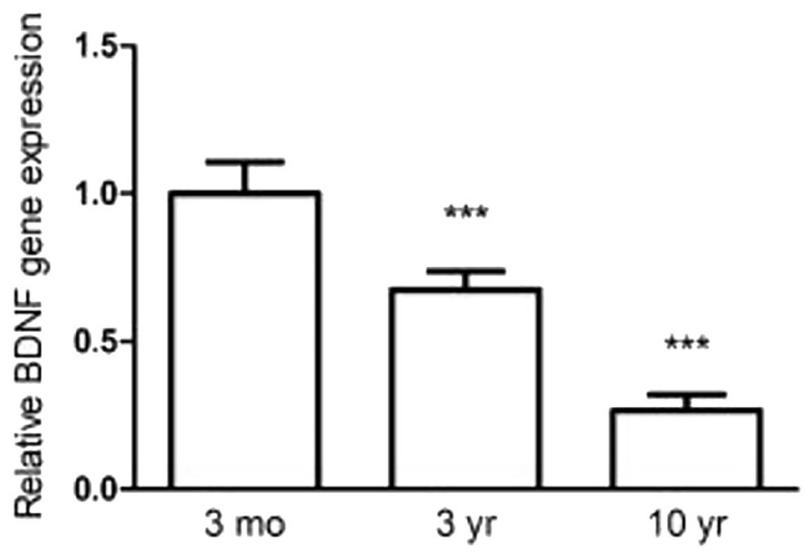

Fig. 3. Relative gene expression ratios of (A) PAC1 and (B) BDNF measured from mammary gland tissue samples of 3-month- (3 mo), 3-year- $(3 \mathrm{yr})$ and 10-year-old (10 yr) female sheep ( $n=4 /$ group). Statistical analysis: one-way ANOVA, Bonferroni's post test. Results are shown as means \pm SEM, $* * * P<0.0001$.

\section{No change of VIP concentration in the plasma and milk in lactating ewes and lambs}

VIP concentration in suckling lambs was approximately $20 \mathrm{pg} / \mathrm{mL}$ in lambs before suckling and, in contrast to PACAP, it did not change either $1 \mathrm{~h}$ or $2 \mathrm{~h}$ after suckling (Fig. $4 \mathrm{~A}$ ). In lactating ewes, we measured almost 2-fold higher peptide concentration in the milk whey compared to mammary and jugular vein plasma samples $(P=0.0004$ and $P=0.0027$ respectively, Fig. $4 \mathrm{~B})$. Plasma VIP content was not altered during aging, it was similar in the 3-month-old lambs, 3year- and in 10-year-old sheep (Fig. 4C). 


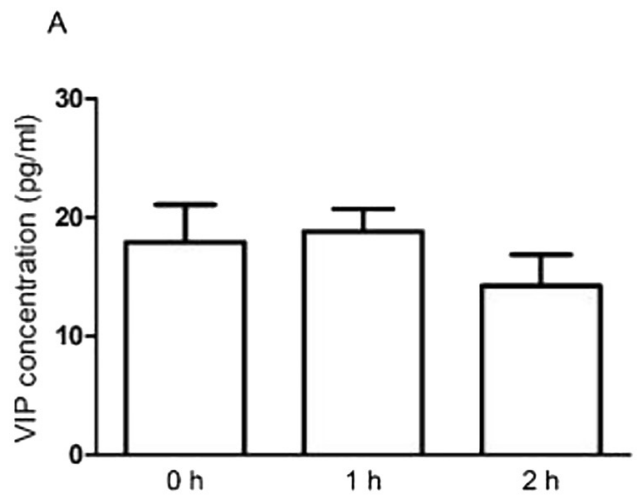

B

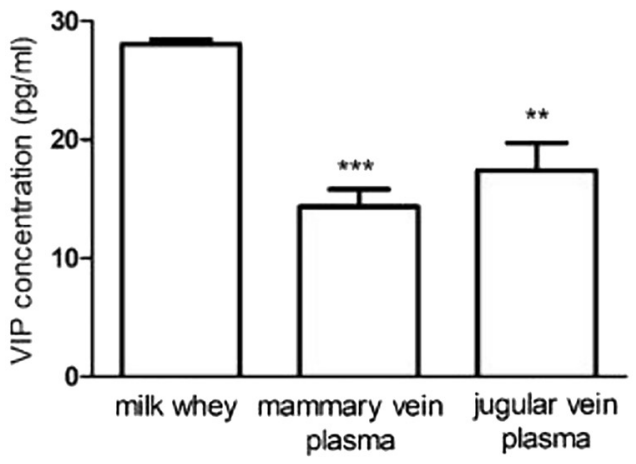

$\mathrm{C}$

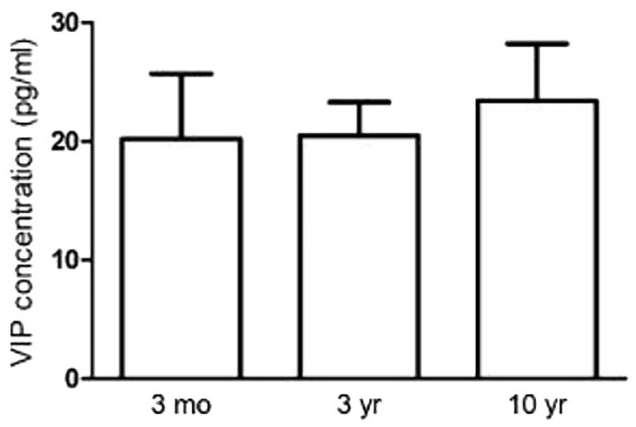

Fig. 4. VIP-like immunoreactivity measured by ELISA (A) in the lamb plasma before, as well as 1 and $2 \mathrm{~h}$ after suckling $(n=9)$, in comparison with milk whey of (B) 3-year-old mother ewes $(n=8)$ and (C) plasma VIP-LI in the jugular vein of the 3 age groups $(n=4$ /group). Statistical analysis: one-way ANOVA, Bonferroni's post test. Results are shown as means \pm SEM, $* * P<0.005, * * * P<0.0001$. Abbreviations: mo: months, yr: years 


\section{DISCUSSION}

We provide here the first evidence for the expression of PACAP38, but not the related peptide VIP, in the mammary gland of lactating ewes, its high concentration in the milk independently of the daily cycle, and its rapid increase in the lamb plasma $1 \mathrm{~h}$ after suckling.

Our previous measurements revealed that both fresh and pasteurized cow milk as well as cow milk-based formulas contain the same amount of PACAP as human milk [9-11]. In human milk, the peptide is present at a constantly high level until 10 months after delivery and increases thereafter [9]. Its level does not differ in foremilk compared to hindmilk during suckling [10].

Although the source of PACAP in the milk is not known, we showed significantly increased plasma PACAP concentration $1 \mathrm{~h}$ after suckling, which decreased close to the basal level $2 \mathrm{~h}$ later. Despite the lack of available data in the literature, the explanation for our findings might be a rapid absorption of PACAP38 from the milk in the proximal part of the gastrointestinal tract in lambs and/or suckling-induced PACAP release from the brain or peripheral tissues.

Although we did not find any difference in plasma PACAP38-LI between the jugular and mammary veins, we found an increasing tendency of PACAP mRNA expression in the mammary gland of 3-year- and 10-year-old ewes. We propose that the high PACAP content of the milk is likely to be derived from the plasma or locally released from the mammary gland. Regarding the potential role of PACAP in the milk, it can directly act on the infant intestinal tract and/or influence the development and maturation of different organs [19-22]. Moreover, PACAP can also affect development, growth and hormonal activity of the mammary gland itself [9].

It has been described that during lactation, VIP plays a role as a potent prolactin-releasing factor in the pituitary in a paracrine and/or autocrine manner. We detected high amounts of VIP in sheep milk whey compared to the plasma, similarly to previous findings in human milk $[23,24]$. We also showed the lack of VIP-specific mRNA in the udder in sheep, in accordance with former observations in rats [23]. Based on our data, we propose that the VIP content of milk is derived from the maternal circulation. Furthermore, besides VIP, we did not detect any specific mRNA in these samples for VPAC 1/2 receptors either. However, this result may be due to technical issues, since there are only predicted and partial coding sequences for the sheep VPACR $1 / 2$ available in the databases, and it is possible that this record does not have all the necessary start or stop sequences. VIP expression in the hypothalamus was shown to be regulated by estrogens in female rats [25], which suggests that VIP might be altered by the peripherial estrogen-dependent condition in the sheep. We investigated the age-dependent VIP level in the plasma, but did not detect any differences between sexually immature lambs, mature young or old adult ewes.

It is known that PACAP and VIP regulate the expression and actions of the BDNF neurotrophic factor in the CNS. This neurotrophin has also been implicated in non-neuronal tissues [26], but its role has not been clarified. Our results are consistent with previous data [14] where strong expression of BDNF was found in lambs and in mature sheep before lambing, but gradually decreasing expression during lactation. We observed significant BDNF mRNA down-regulation both in 3- and 10-year-old sheep, but there were no correlations between BDNF and either PACAP or PAC1 receptor gene expression.

The major novelty of the present study is that we provide the first data for a rapid increase of PACAP38 in the lamb plasma after suckling with the help of highly sensitive and specific analytical methods. The limitation of the results is that the source and the role of PACAP is not possible to experimentally access in small ruminants, therefore only a hypothesis can be 
suggested. However, the present results clearly open new perspectives for elucidating the function of PACAP in the developing newborns, as well as a local role in the mammary gland.

\section{ACKNOWLEDGEMENT}

This research was supported by the Hungarian grant KTIA_NAP_13-2014-0022, University of Debrecen (RH/885/2013), EFOP-3.6.2-16-2017-00006; EFOP-3.6.3-VEKOP-16-15-2017-00008 project "The role of neuroinflammation in neurodegeneration: from molecules to clinics"; Higher Education Institutional Excellence Programme of the Ministry of Human Capacities in Hungary: 20765/3/2018/FEKUTSTRAT, FIKPII; National Scientific Research Fund (OTKA K115874); the National Research, Development and Innovation Fund (K119759); GINOP-2.3.2-15-2016-00050 ("Pepsys"), PTE AOK KA-2019-30 Research grant; National Brain Research program (KTIA_13_ NAP-A-III/5); MTA TKI 14016 Program and Bolyai Scholarship. The present scientific contribution is dedicated to the 650th anniversary of the foundation of the University of Pécs, Hungary.

\section{REFERENCES}

[1] Miyata A, Arimura A, Dahl RR, Minamino N, Uehara A, Jiang L, et al. Isolation of a novel 38 residuehypothalamic polypeptide which stimulates adenylate cyclase in pituitary cells. Biochem Biophys Res Commun 1989; 164(1).

[2] Bourgault S, Vaudry D, Botia B, Couvineau A, Laburthe M, Vaudry H, et al. Novel stable PACAP analogs with potent activity towards the PAC1 receptor. Peptides 2008; 29: 919-32.

[3] Reglődi D, Tamás A. Pituitary Adenilate Cyclase Activating Polypeptide -PACAP Springer International Publishing; 2016.

[4] Moody TW, Ito T, Osefo N, Jensen RT. VIP and PACAP: recent insights into their functions/roles in physiology and disease from molecular and genetic studies. Curr Opin Endocrinol Diabetes Obes 2011; $18(1)$.

[5] Vaudry D, Gonzales BJ, Basille M, Yon L, Fournier A, Vaudry H. Pituitary adenylate cyclase-activating polypeptide and its receptors: from structure to functions. Pharmacol Rev 2000; 52(2): 269-324.

[6] Grosvernor CE, Picciano MF, Baumrucker CR. Hormones and growth factors in milk. Endocr Rev 1993; 14: $710-28$.

[7] Cohick WS. Role of the insulin-like growth factors and their binding proteins in lactation. J Dairy Sci 1998; 81: 1769-77.

[8] Schlimme E, Martin D, Meisel H. Nucleosides and nucleotides: natural bioactive substances in milk and colostrum. Br J Nutr 2000; 84: 59-68.

[9] Csanaky K, Bánki E, Szabadfi K, Reglödi D, Tarcai I, Czeglédi L, et al. Changes in PACAP immunoreactivity in human milk and presence of PAC1 receptor in mammary gland during lactation. J Mol Neurosci 2012; 48: 631-7.

[10] Csanaky K, Reglődi D, Bánki E, Tarcai I, Márk L, Helyes Zs, et al. Examination of PACAP38-like immunoreactivity in different milk and infant formula samples. Acta Physiol Hung 2013; 100: 28-36.

[11] Czeglédi L, Tamás A, Börzsei R, Bagoly T, Kiss P, Horváth G, et al. Presence of pituitary adenylate cyclaseactivating polypeptide (PACAP) in the plasma and milk of ruminant animals. Gen Comp Endocrinol 2011; 172: 115-9. 
[12] Reglődi D, Atlasz T, Szabó E, Jüngling A, Tamás A, Juhász T, et al. PACAP deficiency as a model of aging. GeroScience 2018; 40: 437-52.

[13] Pellegri G, Magistretti PJ, Martin JL. VIP and PACAP potentiate the action of glutamate on BDNF expression in mouse cortical neurones. Eur J Neurosci 1998; 10: 272-80.

[14] Colitti M. Expression of NGF, BDNF and their high-affinity receptors in ovine mammary glands during development and lactation. Histochem Cell Biol 2015; 144: 559-70.

[15] Helyes Zs, Pozsgai G, Börzsei R, Németh J, Bagoly T, Márk L, et al. Inhibitory effect of PACAP-38 on acute neurogenic and non-neurogenic inflammatory processes in the rat. Peptides 2007; 28: 1847-55.

[16] Jakab B, Reglődi D, Józsa R, Hollósy T, Tamás A, Lubics A, et al. Distribution of PACAP-38 in the central nervous system of various species determined by a novel radioimmunoassay. J Biochem Biophys Methods 2004; 61: 189-98.

[17] Broad TE, Dolling CHS, Lauvergne JJ, Millar P. Revised COGNOSAG guidelines for gene nomenclature. Genet Sel Evol 1999; 31: 263-8.

[18] Pfaffl MW. A new mathematical model for relative quantification in real-time RT-PCR. Nucleic Acids Res 2001; 29: e45.

[19] Fülöp DB, Humli V, Szepesy J, Ott V, Reglödi D, Gaszner B, et al. Hearing impairment and associated morphological changes in pituitary adenylate cyclase activating polypeptide (PACAP)-deficient mice. Sci Rep 2019; 9: 14598.

[20] Juhász T, Matta C, Katona E, Somogyi C, Takács R, Gergely P, et al. Pituitary adenylate cyclase activating polypeptide (PACAP) signalling exerts chondrogenesis promoting and protecting effects: implication of calcineurin as a downstream target. PLoS One 2014; 9:e91541.

[21] Sándor B, Fintor K, Fálszeghy S, Juhász T, Reglödi D, Márk L, et al. Structural and morphometric comparison of the molar teeth in pre-eruptive developmental stage of PACAP-deficient and wild-type mice. J Mol Neurosci 2014; 54: 331-41.

[22] Szegeczki V, Bauer B, Jüngling A, Fülöp BD, Vágó J, Perényi H, et al. Age-related alterations of articular cartilage in pituitary adenylate cyclase-activating polypeptide (PACAP) gene-deficient mice. GeroScience 2019; 41(6): 775-93.

[23] Koch Y, Werner H, Fridkin M. Hypothalamic hormones in milk. Endocr Regul 1991; 25: 128-33.

[24] Werner H, Koch Y, Fridkin M, Fahrenkrug J, Gozes I. High levels of vasoactive intestinal peptide in human milk. Biochem Biophys Res Commun 1985; 133: 228-32.

[25] Gozes I, Werner H, Fawzi M, Abdelatty A, Shani Y, Fridkin M, et al. Estrogen regulation of vasoactive intestinal peptide mRNA in rat hypothalamus. J Mol Neurosci 1989; 1: 55-61.

[26] Braun A, Lommatzsch M, Mannsfeldt A, Neuhaus-Steinmetz U, Fischer A, Schnoy N, et al. Cellular sources of enhanced brain-derived neurotrophic factor production in a mouse model of allergic inflammation: notice to professional pecruitment and announcement advertisers. Am J Respir Cell Mol Biol 1999; 21: 537-46.

\section{SUPPLEMENTARY DATA}

Supplementary data to this article can be found online at https://doi.org/10.1556/2060.2020. 00006

Open Access statement. This is an open-access article distributed under the terms of the Creative Commons Attribution 4.0 International License (https://creativecommons.org/licenses/by/4.0/), which permits unrestricted use, distribution, and reproduction in any medium, provided the original author and source are credited, a link to the CC License is provided, and changes - if any - are indicated. (SID_1) 